\title{
18. PYROLYSIS STUDY OF ORGANIC MATTER FROM DEEP SEA DRILLING PROJECT SITES 370 (LEG 41), 415, AND 416 (LEG 50)
}

\author{
A. Boutefeu, Labofina S. A. (Centre de Recherches du Groupe Pétrofina), Brussels, Belgium ${ }^{1}$
}

\begin{abstract}
We analyzed 180 samples of Pleistocene to Tithonian sediments, using the pyrolysis technique. The results show a preponderance of detrital continental organic matter. Most samples contain altered organic matter and are in an immature stage of evolution. A detailed examination of the pyrolysis and depth data shows a correlation between lithology and depositional environment.
\end{abstract}

\section{INTRODUCTION}

Drilling at DSDP Sites 370,415 , and 416 in the Moroccan Basin (Figure 1) provided a good opportunity to apply the rapid pyrolysis technique to a great number of samples from Pleistocene to Tithonian sediments comprising turbidite and hemipelagic facies. In this study the organic matter is characterized, and an attempt is made to determine the relationships among origin and preservation of the organic matter, composition, depositional environment, and sedimentation.

Analytical data are presented in Tables 1 and 2 .

Pyrolysis equipment was first used on board the Glomar Challenger during Leg 48. The prototype was again employed during Leg 50, so that rapid tests for possible "oil shows" could be made - a requirement of the JOIDES Safety and Pollution Prevention Panel.

\section{ANALYTICAL METHODS}

\section{Pyrolysis}

The pyrolysis technique for determination of petroleum potential has recently been applied by many workers (Barker, 1974; Claypool and Reed, 1976). The method and apparatus employed are fully described by Espitalié et al. (1977), and only the essential features are noted here. The sample is crushed to pass through a 60-mesh sieve. A portion is then chemically decomposed in a stream of helium at a programmed rate of temperature increase of $25^{\circ} \mathrm{C} / \mathrm{min}$. Free hydrocarbons (i.e., hydrocarbons present in the rock) are volatilized at a temperature lower than $300^{\circ} \mathrm{C}$ (peak $S_{l}$ in Figure 2). The $S_{2}$ peak in Figure 2 records hydrocarbon compounds produced by the cracking of kerogen between $300^{\circ} \mathrm{C}$ and $575^{\circ} \mathrm{C}$. The curve generally shows a shoulder $\left(S_{2}{ }^{\prime}\right.$, Figure 2$)$, the form of which depends upon the type of organic matter present and its level of maturation. The total content of hydrocarbons (i.e., $S_{1}$ plus $S_{2}$ ) represents the petroleum potential of the sample, whereas $S_{2}$ indicates the residual petroleum potential or the quantity of hydrocarbon that the rock could still produce should

\footnotetext{
${ }^{1}$ Present address: Petrangol, CP 1320, Luanda, Republic of Angola.
}

burial and maturation continue. These potentials are expressed in kilograms of hydrocarbons per metric ton of rock (kg HC/metric ton). The $S_{3}$ peak records the organic $\mathrm{CO}_{2}$ trapped during pyrolysis up to $390^{\circ} \mathrm{C}$ and, at the end of the temperature increase, carried to a thermal-conductivity detector. The ratios $S_{2} / \mathrm{C}_{\text {org }}$ and $\mathrm{S}_{3} / \mathrm{C}_{\text {org }}$ (expressed in milligrams of $\mathrm{HC}$ or $\mathrm{CO}_{2}$ per gram of $\mathrm{C}_{\mathrm{org}}$ ) are known respectively as the "hydrocarbon index" and the "oxygen index" and are correlative with the $\mathrm{H} / \mathrm{C}$ and $\mathrm{O} / \mathrm{C}$ ratios used in the Van Krevelen diagram. On the basis of such a graph, we can define three main types of kerogens (Tissot et al., 1974). Type I has a high potential for generating liquid hydrocarbons, whereas type III has a low potential for generating liquid hydrocarbons and is more likely to yield gaseous hydrocarbons. The production index, $S_{l} /\left(S_{1}+S_{2}\right)$, given in per cent, and the temperature at the maximum of the $S_{2}$ peak, $\left(T_{M}\right)$, are indicators of the thermal maturity of the organic matter (Barker, 1974; Espitalié et al., 1977).

\section{Organic-Carbon Determination}

Crushed samples were treated with 10 per cent $\mathrm{HCl}$ at $70^{\circ} \mathrm{C}$ for a time varying according to the estimated carbonate content of the sample. The resulting weight loss is attributed entirely to carbonate. The organic-carbon content $(\%)$ was determined on the residue with a LECO WR 12 carbon analyzer.

\section{RESULTS AND INTERPRETATION}

\section{Preliminary Remarks}

Some samples from Sites 370,415 , and 416 show a supplementary peak (or shoulder) between $S_{l}$ and $S_{2}$ (Figure 3). Experiments on recent sediments show that this intermediate peak seems to be characteristic of immature organic matter. In the majority of cases it disappears after the sample has been treated with hydrochloric acid. This intermediate peak, however, probably is not caused solely by the presence of hydrolyzable carbon, expecially in the deeply buried sediments, such as Sample 416A-32-3, 11-15 cm, from a depth of 1397 meters. The intermediate peak accounts for at least 15 per cent of the hydrocarbons evolved above $300^{\circ} \mathrm{C}$ in this sample. A part of this peak could also be caused by the release of hydrocarbons weakly bonded to kerogen 


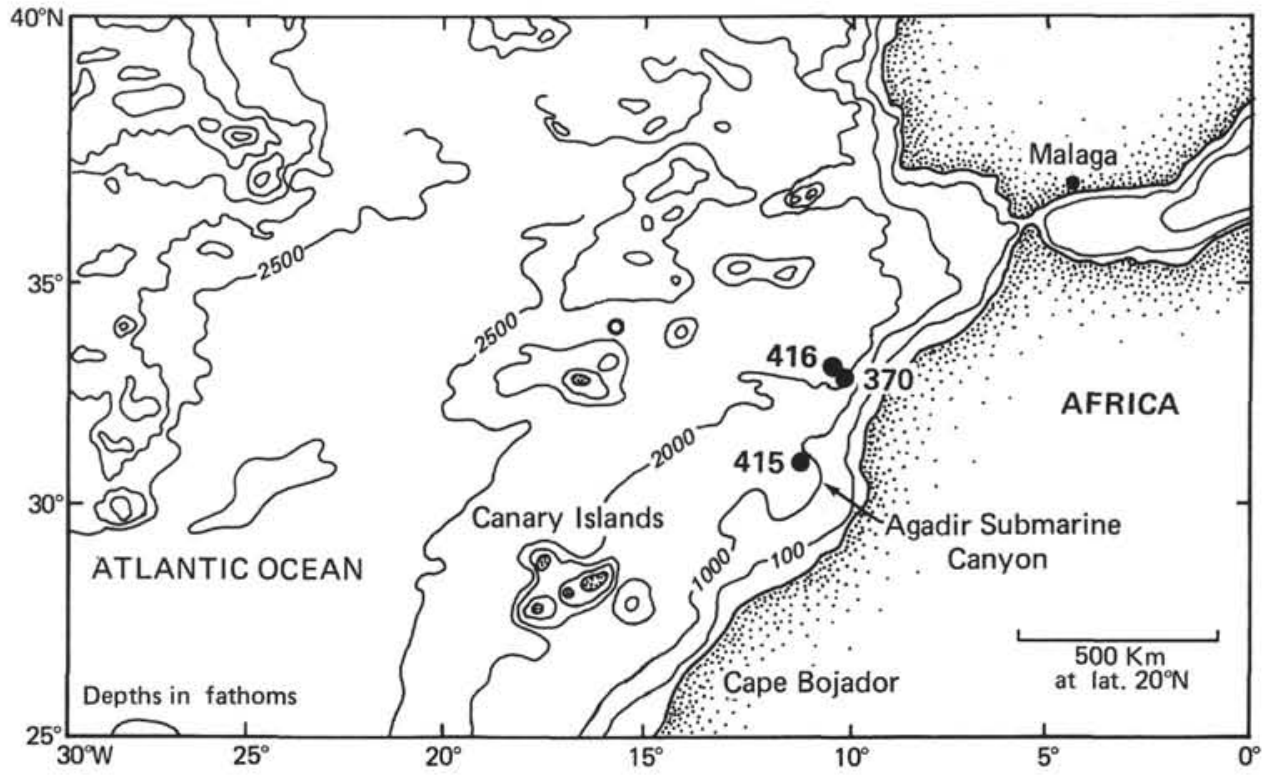

Figure 1. Location of DSDP Sites 370, 415, and 416.

TABLE 1

Pyrolysis Data for Site 415

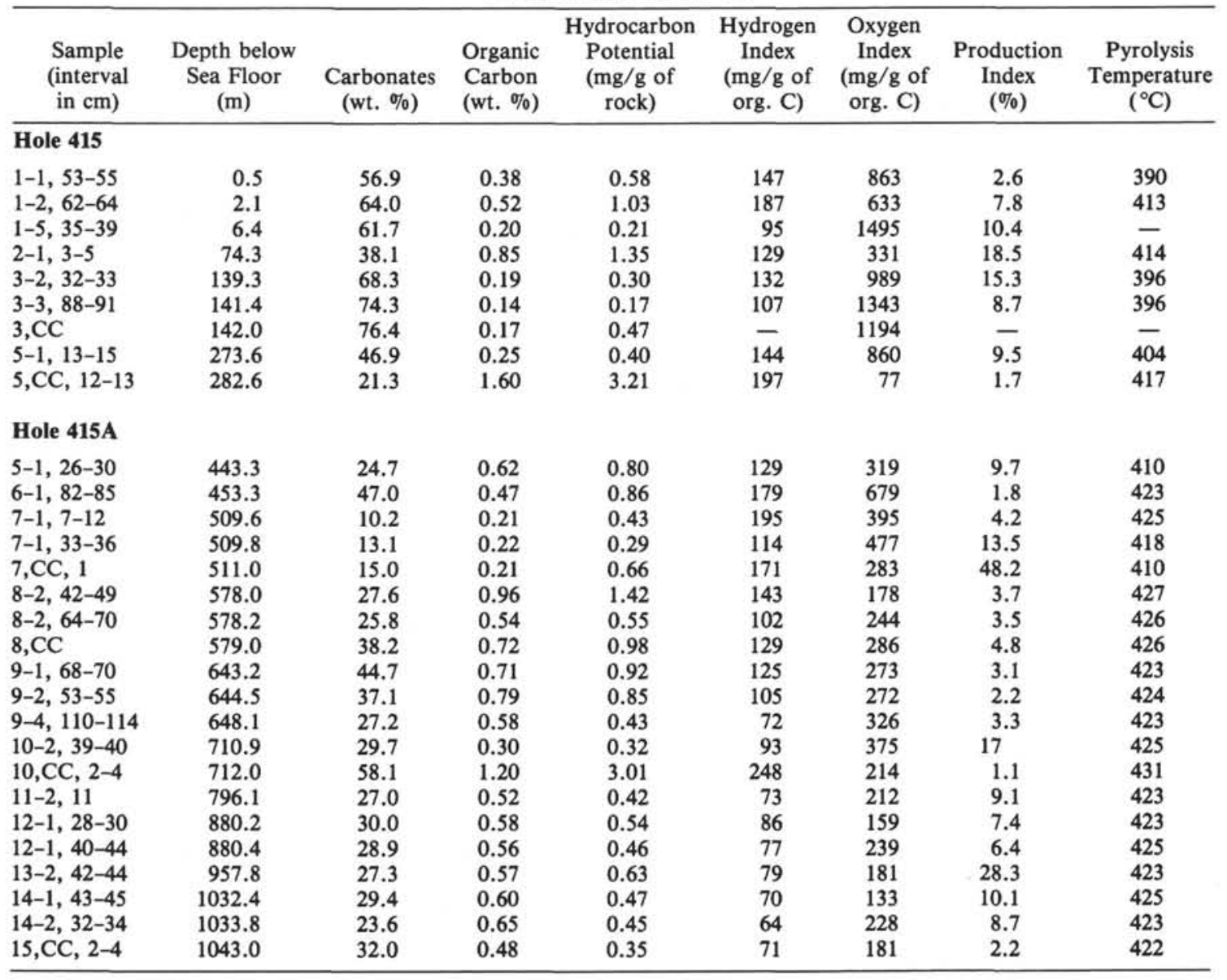


TABLE 2

Pyrolysis Data for Site $\mathbf{4 1 6}$

\begin{tabular}{|c|c|c|c|c|c|c|c|c|}
\hline $\begin{array}{l}\text { Sample } \\
\text { (interval } \\
\text { in } \mathrm{cm} \text { ) }\end{array}$ & $\begin{array}{l}\text { Depth below } \\
\text { Sea Floor } \\
\text { (m) }\end{array}$ & $\begin{array}{c}\text { Carbonates } \\
\text { (wt. \%) }\end{array}$ & $\begin{array}{l}\text { Organic } \\
\text { Carbon } \\
\text { (wt. \%) }\end{array}$ & $\begin{array}{l}\text { Hydrocarbon } \\
\text { Potential } \\
\text { (mg/g of } \\
\text { rock) }\end{array}$ & $\begin{array}{l}\text { Hydrogen } \\
\text { Index } \\
\text { (mg/g of } \\
\text { org. C) }\end{array}$ & $\begin{array}{l}\text { Oxygen } \\
\text { Index } \\
\text { (mg/g of } \\
\text { org. C) }\end{array}$ & $\begin{array}{l}\text { Production } \\
\text { Index } \\
(\%)\end{array}$ & $\begin{array}{c}\text { Pyrolysis } \\
\text { Temperature } \\
\left({ }^{\circ} \mathrm{C}\right)\end{array}$ \\
\hline \multicolumn{9}{|l|}{ Hole 416A } \\
\hline $1-1,53-55$ & 146.5 & 79.9 & 0.10 & 0.20 & - & - & - & - \\
\hline $1-2,27-28$ & 147.8 & 34.3 & 1.00 & 2.02 & 195 & 184 & 3.2 & 417 \\
\hline $1, \mathrm{CC}, 8-9$ & 149.1 & 57.6 & 0.18 & 0.35 & - & - & - & - \\
\hline $2-1,41-42$ & 298.4 & 34.7 & 0.76 & 1.25 & 162 & 162 & 1.5 & 419 \\
\hline $2-1,42-45$ & 298.4 & 36.3 & 0.70 & 0.89 & 124 & 277 & 2.3 & 414 \\
\hline $2-2,48-50$ & 300.0 & 37.2 & 0.62 & 0.87 & 136 & 290 & 3.6 & 417 \\
\hline $2-3,109-150$ & 302.2 & 38.0 & 0.60 & 0.73 & 118 & 368 & 3.2 & 411 \\
\hline $2-4,50-51$ & 303.0 & 38.1 & 0.30 & 0.49 & 150 & 483 & 6.9 & 407 \\
\hline $3-1,68-70$ & 450.7 & 34.7 & 0.74 & 1.21 & 160 & 327 & 2.1 & 412 \\
\hline $3-2,113-115$ & 452.6 & 33.8 & 0.78 & 0.97 & 123 & 332 & 1.3 & 413 \\
\hline $3-3,66-68$ & 453.7 & 33.7 & 1.05 & 2.27 & 213 & 263 & 1.5 & 421 \\
\hline $5, \mathrm{CC}, 27-28$ & 755.8 & 14.6 & 1.71 & 4.61 & 267 & 267 & 1.1 & 429 \\
\hline $6-2,17-18$ & 892.7 & 13.7 & 1.59 & 2.99 & 186 & 69 & 1.4 & 423 \\
\hline $6-3,127$ & 895.3 & 8.4 & 2.05 & 5.83 & 283 & 60 & 0.6 & 427 \\
\hline $6-4,1-4$ & 895.5 & 8.3 & 1.53 & 2.53 & 164 & 58 & 0.8 & 428 \\
\hline $7-1,15-20$ & 991.7 & 18.1 & 0.44 & 0.53 & 111 & 210 & 8.1 & 422 \\
\hline $7-1,34-36$ & 991.8 & 30.3 & 0.05 & - & - & - & - & - \\
\hline $7-3,25-30$ & 994.8 & 19.0 & 0.37 & 0.30 & 78 & 249 & 1.9 & 425 \\
\hline $7-3,91-93$ & 995.4 & 28.2 & 0.21 & 0.32 & 151 & 333 & 0.0 & 423 \\
\hline $9-1,12-17$ & 1177.0 & 17.6 & 0.36 & 0.29 & 74 & 272 & 3.1 & 427 \\
\hline $9-1,64-66$ & 1177.5 & 15.6 & 0.51 & 0.49 & 92 & 231 & 4.5 & 423 \\
\hline $9-1,73-77$ & 1177.6 & 29.0 & 0.16 & 0.19 & 92 & 313 & 22.0 & 425 \\
\hline $9-1,94-95$ & 1177.8 & 29.2 & 0.35 & 0.60 & 163 & 186 & 5.3 & 426 \\
\hline $9-5,68-70$ & 1183.6 & 26.4 & 0.84 & 1.31 & 152 & 223 & 2.4 & 427 \\
\hline $10-2,140-143$ & 1188.3 & 18.7 & 0.54 & 0.56 & 100 & 259 & 3.1 & 426 \\
\hline $11-1,98-102$ & 1195.8 & 28.1 & 0.44 & 0.43 & 96 & 373 & 3.2 & 425 \\
\hline $11-3,90-94$ & 1198.7 & 22.0 & 0.39 & 0.37 & 92 & 300 & 3.5 & 423 \\
\hline $11-3,112-114$ & 1198.9 & 24.2 & 1.23 & 1.58 & 126 & 89 & 2.1 & 437 \\
\hline $11-5,117-120$ & 1202.0 & 16.1 & 0.60 & 0.52 & 85 & 248 & 2.9 & 426 \\
\hline $12-1,72-74$ & 1205.0 & 29.3 & 0.81 & 1.13 & 137 & 189 & 1.5 & 424 \\
\hline $12-3,63-67$ & 1207.9 & 16.5 & 0.56 & 0.44 & 76 & 136 & 3.1 & 429 \\
\hline $13-2,110-112$ & 1214.9 & 10.5 & 0.94 & 0.81 & 85 & 128 & 2.0 & 429 \\
\hline $14-2,0-4$ & 1224.9 & 16.0 & 0.38 & 0.29 & 73 & 266 & 2.6 & 429 \\
\hline $14-5,25-27$ & 1229.7 & 12.6 & 0.58 & 0.49 & 82 & 162 & 3.6 & 425 \\
\hline $14, \mathrm{CC}, 30-33$ & 1232.7 & 26.7 & 0.37 & 0.29 & 76 & 143 & 2.7 & 427 \\
\hline $15-4,100-103$ & 1238.4 & 25.8 & 0.47 & 0.45 & 93 & 268 & 2.7 & 426 \\
\hline $15-6,16-20$ & 1240.6 & 9.5 & 0.38 & 0.28 & 71 & 134 & 2.2 & 426 \\
\hline $16-1,80-82$ & 1243.3 & 37.9 & 0.60 & 0.74 & 121 & 207 & 2.1 & 424 \\
\hline $16-2,83-84$ & 1244.8 & 12.2 & 1.93 & 4.23 & 218 & 42 & 0.5 & 421 \\
\hline $16-3,13-15$ & 1245.6 & 10.9 & 0.45 & 0.47 & 99 & 141 & 3.8 & 425 \\
\hline $16-4,133-136$ & 1248.1 & 11.0 & 0.39 & 0.27 & 68 & 138 & 1.8 & 429 \\
\hline $17-1,55-58$ & 1252.5 & 23.6 & 0.39 & 0.34 & 79 & 346 & 9.2 & 426 \\
\hline $17-3,83-85$ & 1255.9 & 16.6 & 0.46 & 0.45 & 84 & 222 & 14.6 & 426 \\
\hline $18-4,96-98$ & 1267.0 & 35.7 & 0.84 & 1.52 & 176 & 206 & 2.8 & 427 \\
\hline $19-3,79-84$ & 1274.8 & 20.5 & 0.65 & 0.56 & 83 & 197 & 3.9 & 424 \\
\hline $19, \mathrm{CC}, 0-2$ & 1278.5 & 28.1 & 0.57 & 0.70 & 118 & 253 & 3.3 & 424 \\
\hline $20-3,29-30$ & 1280.8 & 29.6 & 0.59 & 0.77 & 127 & 227 & 3.4 & 425 \\
\hline $21-1,50-54$ & 1290.5 & 23.6 & 0.39 & 0.33 & 81 & 308 & 3.7 & 426 \\
\hline $21-4,82-84$ & 1295.3 & 24.7 & 0.47 & 0.44 & 93 & 311 & 1.7 & 422 \\
\hline $22-3,141-143$ & 1303.9 & 14.1 & 0.38 & 0.30 & 75 & 261 & 5.2 & 427 \\
\hline $22-4,0-3$ & 1304.0 & 31.9 & 0.23 & 0.21 & 88 & 248 & 2.5 & 424 \\
\hline $22-4,3-5$ & 1304.0 & 31.3 & 0.58 & 0.80 & 133 & 191 & 2.9 & 429 \\
\hline $23-2,101-103$ & 1311.6 & 31.8 & 0.40 & 0.28 & 67 & 168 & 3.1 & 432 \\
\hline $23-3,20-23$ & 1312.2 & 32.2 & 0.43 & 0.41 & 93 & 337 & 1.7 & 426 \\
\hline $24-2,58-59$ & 1320.7 & 14.0 & 15.23 & 45.07 & 296 & 40 & 0.0 & 409 \\
\hline $24-2,64-65$ & 1320.7 & 19.8 & 0.95 & 0.80 & 83 & 81 & 0.9 & 430 \\
\hline $24-3,35-39$ & 1321.9 & 38.1 & 0.57 & 0.43 & 72 & 514 & 5.3 & 425 \\
\hline $25, \mathrm{CC}, 10-12$ & 1335.3 & 26.0 & 0.29 & 0.26 & 82 & 438 & 8.0 & 429 \\
\hline $26-1,32-34$ & 1337.5 & 50.4 & 0.61 & 0.74 & 118 & 184 & 1.9 & 428 \\
\hline $26-3,70-72$ & 1340.9 & 14.4 & 0.44 & 0.43 & 93 & 320 & 5.7 & 422 \\
\hline $27-1,128-131$ & 1348.0 & 9.6 & 0.41 & 0.14 & 32 & 93 & 6.4 & 433 \\
\hline $27-5,79-81$ & 1353.7 & 15.7 & 0.49 & 0.60 & 106 & 253 & 13.1 & 424 \\
\hline $28-1,101-107$ & 1357.2 & 16.3 & 0.51 & 0.39 & 71 & 286 & 5.3 & 425 \\
\hline $28-6,123-125$ & 1364.9 & 17.5 & 0.40 & 0.51 & 98 & 495 & 23.7 & 426 \\
\hline $29-3,12-14$ & 1368.8 & 11.6 & 0.39 & 0.43 & 106 & 167 & 4.4 & 426 \\
\hline
\end{tabular}


TABLE 2 - Continued

\begin{tabular}{|c|c|c|c|c|c|c|c|c|}
\hline $\begin{array}{l}\text { Sample } \\
\text { (interval } \\
\text { in } \mathrm{cm} \text { ) }\end{array}$ & $\begin{array}{l}\text { Depth below } \\
\text { Sea Floor } \\
\text { (m) }\end{array}$ & $\begin{array}{c}\text { Carbonates } \\
\text { (wt. \%) }\end{array}$ & $\begin{array}{l}\text { Organic } \\
\text { Carbon } \\
\text { (wt. \%) }\end{array}$ & $\begin{array}{l}\text { Hydrocarbon } \\
\text { Potential } \\
\text { (mg/g of } \\
\text { rock) }\end{array}$ & $\begin{array}{l}\text { Hydrogen } \\
\text { Index } \\
\text { (mg/g of } \\
\text { org. C) }\end{array}$ & $\begin{array}{l}\text { Oxygen } \\
\text { Index } \\
\text { (mg/g of } \\
\text { org. C) }\end{array}$ & $\begin{array}{l}\text { Production } \\
\text { Index } \\
(\%)\end{array}$ & $\begin{array}{c}\text { Pyrolysis } \\
\text { Temperature } \\
\left({ }^{\circ} \mathrm{C}\right)\end{array}$ \\
\hline $29-5,112-114$ & 1372.8 & 42.4 & 0.31 & 0.23 & 70 & 684 & 7.4 & 426 \\
\hline $30-1,118-120$ & 1376.4 & 58.1 & 0.32 & 0.48 & 138 & 759 & 8.0 & 422 \\
\hline $30-2,68-70$ & 1377.4 & 51.3 & 0.12 & 0.04 & 30 & 1125 & 0.0 & 430 \\
\hline $31-6,57-62$ & 1392.7 & 8.5 & 0.79 & 0.92 & 111 & 75 & 4.8 & 425 \\
\hline $32-3,11-15$ & 1397.2 & 33.9 & 0.11 & 0.08 & 63 & 800 & 11.8 & 422 \\
\hline $32-4,43-46$ & 1399.0 & 38.3 & 0.12 & 0.10 & 61 & 1358 & 22.7 & 411 \\
\hline $34-2,97-98$ & 1409.3 & 11.5 & 0.11 & 0.10 & 71 & 291 & 22.7 & 371 \\
\hline $34-2,100-102$ & 1409.3 & 12.1 & 0.64 & 0.51 & 76 & 111 & 5.3 & 428 \\
\hline $34-3,134-137$ & 1411.1 & 14.2 & 0.27 & 0.17 & 57 & 230 & 9.3 & 428 \\
\hline $35-2,113-115$ & 1419.1 & 26.9 & 0.34 & 0.30 & 79 & 282 & 8.9 & 423 \\
\hline $35-2,119-121$ & 1419.2 & 19.5 & 0.19 & 0.13 & 62 & 263 & 11.8 & 426 \\
\hline $35-3,28-32$ & 1419.7 & 12.8 & 0.68 & 0.51 & 71 & 118 & 4.6 & 434 \\
\hline $37-1,92-96$ & 1435.9 & 12.7 & 0.17 & 0.13 & 62 & 324 & 20.3 & 426 \\
\hline $37-3,108-110$ & 1439.1 & 45.3 & 0.19 & 0.23 & 58 & 626 & 52.8 & 426 \\
\hline $38-1,40-43$ & 1445.4 & 13.0 & 0.16 & 0.09 & 53 & 444 & 10.7 & 429 \\
\hline $38-1,140-142$ & 1446.4 & 16.5 & 0.23 & 0.15 & 50 & 252 & 26.7 & 426 \\
\hline $38-2,23-25$ & 1446.7 & 28.9 & 0.06 & 0.08 & - & - & - & - \\
\hline $38-2,33-35$ & 1446.8 & 35.1 & 0.08 & 0.06 & 63 & 381 & 14.6 & 434 \\
\hline $40-2,84-88$ & 1456.9 & 19.3 & 0.08 & 0.03 & 25 & 350 & 35.3 & 434 \\
\hline $40-5.133$ & 1461.8 & 12.3 & 0.25 & 0.13 & 54 & 160 & 3.5 & 427 \\
\hline $40-6,99-101$ & 1463.0 & 16.3 & 0.20 & 0.14 & 66 & 170 & 9.2 & 426 \\
\hline $41-3,123-130$ & 1468.1 & 11.6 & 0.27 & 0.13 & 45 & 144 & 7.4 & 424 \\
\hline $41-4,28-30$ & 1468.7 & 32.1 & 0.14 & 0.12 & 70 & 414 & 7.6 & 424 \\
\hline $42-1,38-40$ & 1473.7 & 53.3 & 0.08 & 0.06 & 54 & 988 & 23.1 & 423 \\
\hline $42-1,93-96$ & 1474.2 & 12.1 & 0.18 & 0.11 & 56 & 211 & 7.4 & 425 \\
\hline $42-2,112-114$ & 1475.9 & 10.1 & 0.13 & 0.08 & 55 & 231 & 9.0 & 426 \\
\hline $43-1,10-12$ & 1482.5 & 13.3 & 0.12 & 0.10 & 77 & 333 & 7.3 & 432 \\
\hline $43-4,78-80$ & 1487.7 & 27.8 & 0.10 & 0.13 & 111 & 410 & 11.1 & 413 \\
\hline $44-1,120-122$ & 1493.1 & 6.5 & 0.06 & 0.06 & 85 & 283 & 12.4 & 430 \\
\hline $44-1,122-127$ & 1493.1 & 10.8 & 0.07 & 0.08 & 97 & 271 & 8.9 & 429 \\
\hline $44-2,35-37$ & 1493.8 & 29.8 & 0.32 & 0.20 & 49 & 191 & 21.5 & 426 \\
\hline $45-2,121-127$ & 1503.9 & 9.3 & 0.26 & 0.15 & 54 & 96 & 6.4 & 428 \\
\hline $46-2,0-3$ & 1512.1 & 20.6 & 0.08 & 0.05 & 41 & 250 & 30.6 & 430 \\
\hline $47-2,7-13$ & 1521.6 & 17.7 & 0.07 & 0.04 & 44 & 229 & 30.5 & 436 \\
\hline $47-3,114-118$ & 1524.1 & 14.3 & 0.11 & 0.13 & - & - & - & - \\
\hline $48-1,80-83$ & 1530.3 & 14.4 & 0.19 & 0.15 & 66 & 126 & 14.9 & 430 \\
\hline $48-3,55-59$ & 1533.1 & 26.4 & 0.13 & 0.04 & 32 & 190 & 4.7 & 432 \\
\hline $49-1,86-88$ & 1540.0 & 11.8 & 0.27 & 0.21 & 70 & 89 & 9.7 & 430 \\
\hline $49-1,88-90$ & 1540.0 & 29.7 & 0.10 & 0.16 & - & - & - & - \\
\hline $49-3,19-24$ & 1542.3 & 22.7 & 0.20 & 0.10 & 48 & 170 & 6.2 & 429 \\
\hline $50-1,97-102$ & 1549.6 & 14.7 & 0.18 & 0.08 & 43 & 144 & 8.4 & 431 \\
\hline $50-3,13-16$ & 1551.7 & 20.3 & 0.18 & 0.13 & 68 & 139 & 59.8 & 429 \\
\hline $51-2,80-84$ & 1560.4 & 28.0 & 0.13 & 0.10 & 75 & 408 & 3.1 & 432 \\
\hline $52-1,71-75$ & 1568.1 & 32.3 & 0.07 & 0.07 & 99 & 428 & 2.7 & 431 \\
\hline $53-1,71-74$ & 1577.5 & 8.0 & 0.10 & 0.03 & 29 & 370 & 13.1 & 425 \\
\hline $53-2,91-94$ & 1579.2 & 14.2 & 0.32 & 0.05 & 15 & 178 & 12.2 & 423 \\
\hline $55, \mathrm{CC}, 14-18$ & 1598.7 & 27.8 & 0.11 & 0.04 & - & - & - & - \\
\hline $57-1,81-82$ & 1615.3 & 5.9 & 0.36 & 0.46 & - & - & - & $\overline{10}$ \\
\hline $57-1,83-88$ & 1615.3 & 15.8 & 0.13 & 0.05 & 38 & 369 & 10.5 & 429 \\
\hline \multicolumn{9}{|l|}{ Hole 370} \\
\hline $1-5,47-50$ & 6.5 & 55.6 & 0.42 & 0.47 & 101 & 736 & 8.6 & 407 \\
\hline $2-2,106-108$ & 103.6 & 43.4 & 0.10 & 0.11 & 85 & 1460 & 21.8 & 400 \\
\hline $4-2,37-40$ & 218.4 & 32.6 & 1.02 & 1.45 & 137 & 208 & 3.6 & 415 \\
\hline $5-2,32-35$ & 323.3 & 14.6 & 0.12 & 0.25 & 183 & 592 & 4.6 & 401 \\
\hline $6-2,52-55$ & 428.0 & 11.8 & 0.41 & 0.51 & 121 & 183 & 3.3 & 397 \\
\hline $8-2,66-70$ & 466.2 & 24.4 & 0.69 & 1.06 & 149 & 191 & 2.6 & 416 \\
\hline $9-1,102-105$ & 484.0 & 19.3 & 0.53 & 0.80 & 147 & 192 & 2.9 & 410 \\
\hline $12-1,126-129$ & 541.3 & 23.4 & 1.30 & 4.35 & 330 & 54 & 1.3 & 417 \\
\hline $14-1,48-52$ & 569.0 & 33.9 & 2.54 & 11.52 & 454 & 81 & 0.0 & 422 \\
\hline $15-1,113-116$ & 588.6 & 47.4 & 1.56 & 6.45 & 413 & 142 & 0.0 & 423 \\
\hline $16-2,42-45$ & 608.4 & 64.7 & 1.98 & 10.57 & 534 & 118 & 0.0 & 429 \\
\hline $18-2,95-98$ & 637.4 & 24.2 & 0.70 & 1.34 & 187 & 187 & 2.3 & 429 \\
\hline $19-1,68-73$ & 654.7 & 44.5 & 0.48 & 0.61 & 123 & 450 & 2.7 & 426 \\
\hline $20-2,82-85$ & 675.3 & 31.5 & 0.58 & 0.53 & 89 & 297 & 2.7 & 423 \\
\hline $23-2,52-56$ & 703.5 & 19.5 & 0.43 & 0.27 & 61 & 302 & 4.1 & 424 \\
\hline
\end{tabular}


TABLE 2 - Continued

\begin{tabular}{|c|c|c|c|c|c|c|c|c|}
\hline $\begin{array}{l}\text { Sample } \\
\text { (interval } \\
\text { in } \mathrm{cm} \text { ) }\end{array}$ & $\begin{array}{l}\text { Depth below } \\
\text { Sea Floor } \\
\text { (m) }\end{array}$ & $\begin{array}{c}\text { Carbonates } \\
\text { (wt. } \% \text { ) }\end{array}$ & $\begin{array}{l}\text { Organic } \\
\text { Carbon } \\
\text { (wt. \%) }\end{array}$ & $\begin{array}{l}\text { Hydrocarbon } \\
\text { Potential } \\
\text { (mg/g of } \\
\text { rock) }\end{array}$ & $\begin{array}{l}\text { Hydrogen } \\
\text { Index } \\
\text { (mg/g of } \\
\text { org. C) }\end{array}$ & $\begin{array}{l}\text { Oxygen } \\
\text { Index } \\
\text { (mg/g of } \\
\text { org. C) }\end{array}$ & $\begin{array}{l}\text { Production } \\
\text { Index } \\
(\%)\end{array}$ & $\begin{array}{c}\text { Pyrolysis } \\
\text { Temperature } \\
\left({ }^{\circ} \mathrm{C}\right)\end{array}$ \\
\hline $24-2,47-50$ & 713.0 & 22.8 & 0.60 & 0.42 & 67 & 245 & 3.9 & 420 \\
\hline $26-3,22-25$ & 733.2 & 20.7 & 0.52 & 0.38 & 71 & 194 & 2.3 & 422 \\
\hline $28-2,19-23$ & 769.7 & 5.1 & 0.27 & 0.62 & 223 & 122 & 2.4 & 432 \\
\hline $30-2,31-36$ & 888.8 & 7.1 & 0.17 & 0.36 & 204 & 129 & 3.3 & $441-458$ \\
\hline $31-1,46-50$ & 825.5 & 6.6 & 0.18 & 0.37 & 197 & 167 & 3.1 & $420-459$ \\
\hline $32-3,82-86$ & 838.3 & 18.4 & 4.10 & 17.79 & 431 & 56 & 0.7 & 425 \\
\hline $33, \mathrm{CC}$ & 854.0 & 28.5 & 0.92 & 1.28 & 137 & 167 & 1.4 & 427 \\
\hline $35-2,75-78$ & 884.3 & 39.6 & 1.07 & 2.18 & 203 & 182 & 0.6 & 428 \\
\hline $38-2,11-16$ & 940.6 & 12.7 & 0.30 & 0.25 & 82 & 213 & 2.0 & 425 \\
\hline $39-2,55-59$ & 950.6 & 35.6 & 0.52 & 0.59 & 112 & 244 & 2.0 & 427 \\
\hline $41-2,25-29$ & 988.3 & 19.0 & 0.41 & 0.45 & 108 & 273 & 1.6 & 423 \\
\hline $42-2,14-19$ & 1007.2 & 11.3 & 0.37 & 0.28 & 75 & 305 & 1.3 & 427 \\
\hline $43-2,90-97$ & 1026.9 & 19.3 & 0.53 & 0.52 & 98 & 270 & 1.4 & 423 \\
\hline $44-1,6-10$ & 1043.6 & 22.3 & 0.70 & 0.92 & 130 & 251 & 1.5 & 427 \\
\hline $45-2,43-48$ & 1064.4 & 11.3 & 0.39 & 0.27 & 66 & 226 & 0.4 & 429 \\
\hline $46-5,57-60$ & 1088.1 & 13.9 & 0.46 & 0.43 & 60 & 254 & 36.2 & 428 \\
\hline $47-2,15-19$ & 1102.2 & 9.2 & 0.39 & 0.20 & 48 & 187 & 5.4 & 426 \\
\hline $48-1,97-101$ & 1120.5 & 16.7 & 0.40 & 0.26 & 65 & 315 & 2.2 & 429 \\
\hline $49-1,41-46$ & 1138.9 & 17.1 & 0.31 & 0.26 & 77 & 355 & 8.3 & 427 \\
\hline $51-2,14-18$ & 1168.7 & 22.8 & 0.59 & 0.66 & 104 & 285 & 6.8 & 428 \\
\hline
\end{tabular}

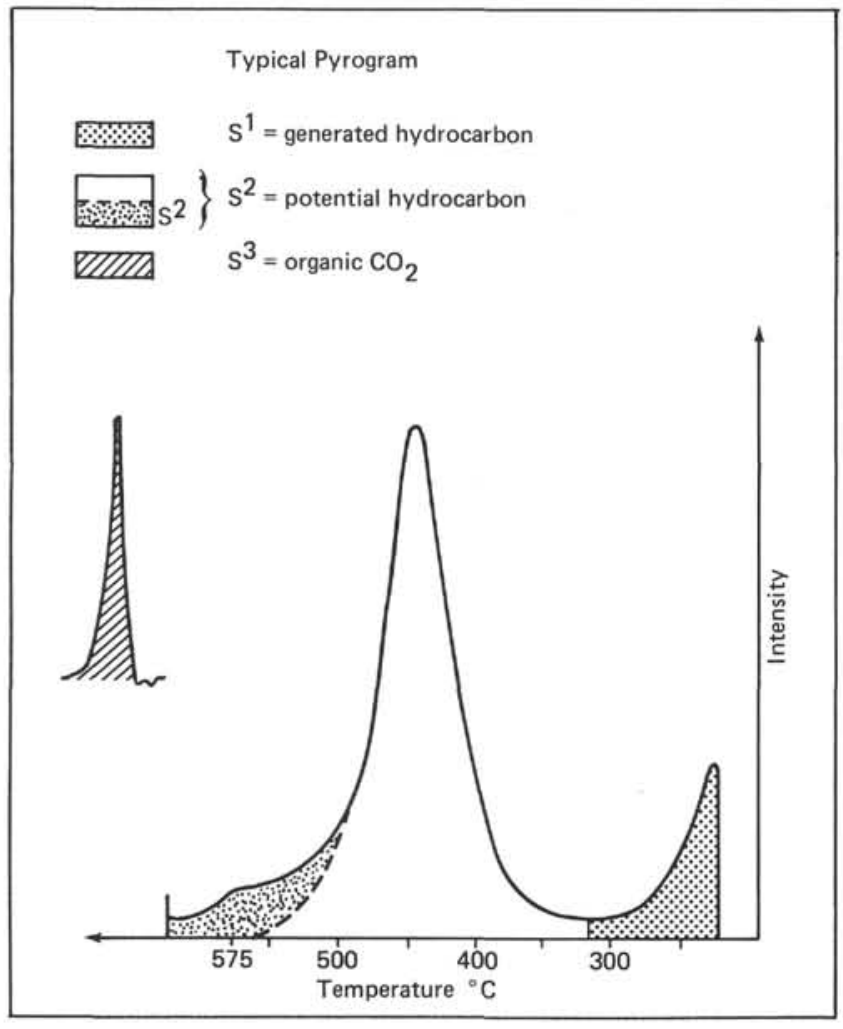

Figure 2. Typical pyrogram.

(Gallegos, 1975; Ishiwatari et al., 1977) or by hydrocarbons entrapped in the kerogen matrix (as in a molecular sieve), which diffuse out of the kerogen as it begins to swell (Yen, 1974; Schmidt-Collerus and Prien, 1974). Whatever the source, I have considered this peak as a part of $S_{2}$ peak, and therefore as residual petroleum potential.

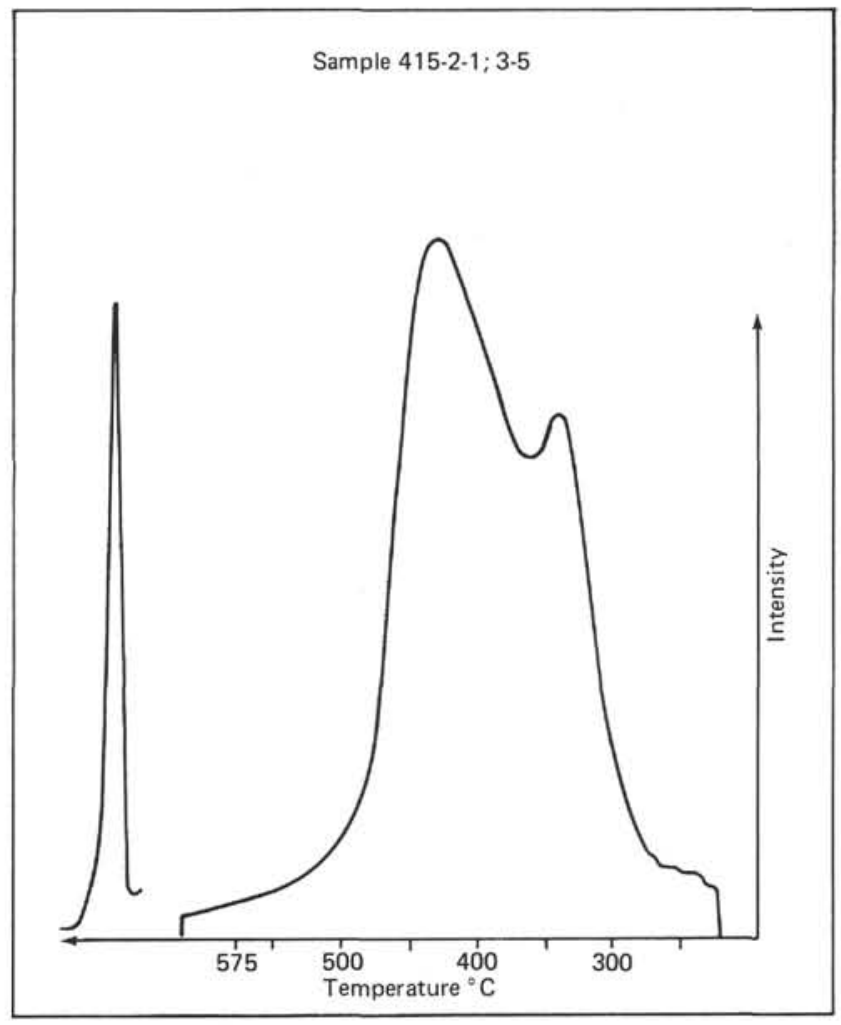

Figure 3. Pyrogram of Sample 415-2-1, 3-5 cm, showing a supplementary peak between 300 and $400^{\circ} \mathrm{C}$.

\section{Site 415}

\section{Vertical Distribution}

I recognize a threefold subdivision of organic-carbon content $\left(\mathrm{C}_{\text {org }}<0.5 \% ; \mathrm{C}_{\text {org }}\right.$ between $0.5 \%$ and $1 \% ; \mathrm{C}_{\text {org }}$ $>1 \%$ ). We also recognize a fourfold subdivision of 


\section{A. BOUTEFEU}

petroleum potential (potential $<0.2 \mathrm{~kg} \mathrm{HC} /$ metric ton; potential between 0.2 and $1 \mathrm{~kg} \mathrm{HC} /$ metric ton; potential between 1 and $2 \mathrm{~kg} \mathrm{HC} /$ metric ton; potential $>2 \mathrm{~kg}$ $\mathrm{HC} /$ metric ton), as well as a fourfold subdivision on the basis of hydrogen index (H.I. $<50 \mathrm{mg} \mathrm{HC} / \mathrm{g} \mathrm{C}_{\text {org }}$; H.I. between 50 and $150 \mathrm{mg} / \mathrm{g}$; H.I. between 150 and 300 $\mathrm{mg} / \mathrm{g}$; H.I. $>300 \mathrm{mg} / \mathrm{g})$. Thus, samples from Site 415 fall into three groups (Figure 4). Given the sparse coring at that site (Site 415 Report, this volume), the vertical extent of each group is uncertain, and there is a possibility that the groups defined are not representative of the entire section.

Group 1 includes the deepest part of the section: the Albian and a great part of the slumped Cenomanian sequence $(1074$ to $650 \mathrm{~m})$. The samples are characterized by an organic-carbon content of about 0.5 per cent and a petroleum potential between 0.3 and $0.6 \mathrm{~kg} \mathrm{HC/}$ metric ton. The hydrogen index increases slightly from $50 \mathrm{mg} / \mathrm{g}$ in the Albian to $100 \mathrm{mg} / \mathrm{g}$ in the Cenomanian.

Group 2 extends from the top of the Cenomanian to the Eocene $(650$ to $300 \mathrm{~m})$. It has an organic-carbon content between 0.5 and 1 per cent and a petroleum potential between 0.4 and $1 \mathrm{~kg} \mathrm{HC} /$ metric ton. The hydrogen index continues to increase slowly upward, from 100 to about $160 \mathrm{mg} / \mathrm{g}$.

Group 3 ranges from lower Miocene to Pleistocene ( 300 to $0 \mathrm{~m}$ ) and is characterized by an organic-carbon content between 0.1 and 1.6 per cent and a petroleum potential between 0.2 and $0.4 \mathrm{~kg} / \mathrm{metric}$ ton. The hydrogen index decreases upward from $170 \mathrm{mg} / \mathrm{g}$ to 120 $\mathrm{mg} / \mathrm{g}$.

As is apparent from Figure 5, the organic matter is located along or below evolution path III and is therefore interpreted as being mainly continental material (Tissot et al., 1974). The very low values of the hydrogen index may be caused by the presence of reworked, altered organic matter. A small contribution of autochthonous marine organic matter could be masked by the presence of altered organic matter. This seems to be confirmed by the positive correlation between organic carbon and carbonate contents in these groups. The correlation suggests that at least some carbonate may be linked to the influx of organic carbon and therefore that a part of the organic carbon is marine.

The slight upward increase of the hydrogen index through the Mesozoic correlates with a decrease in the

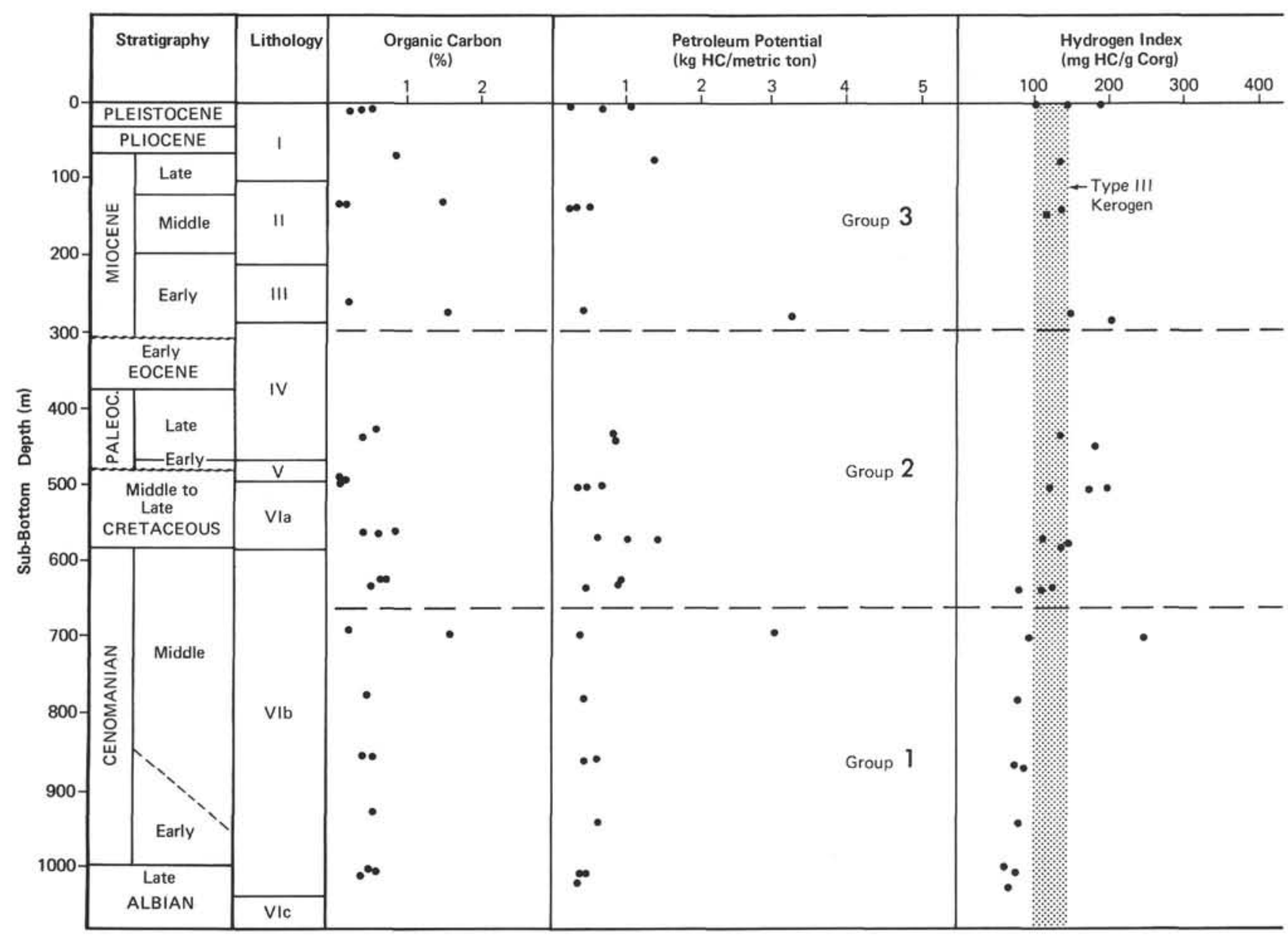

Figure 4. Vertical variations in organic-carbon content, petroleum potential, hydrogen index, pyrolysis temperature, and production index at Site 415. 
influx of terrigenous material (Site 415 Report, this volume).

\section{Petroleum Potential and Maturation of Organic Matter}

The majority of the samples contain more than 0.4 per cent organic carbon (Figure 4), which is considered by many as a minimum value for potential source rock. The hydrocarbon yield from pyrolysis, however, is less than $3 \mathrm{~kg} \mathrm{HC} /$ metric ton $(0.3 \%)$. This is regarded as the minimum value necessary for a rock to have source potential. Indeed, the majority of these samples contain less than 0.08 per cent of pyrolyzable carbon (or effective carbon, in the terminology of Kendrick et al., 1978). This is a consequence of the presence of both continental and reworked and altered organic matter.

All samples are virtually immature, as indicated by the temperature at the maximum of the $S_{2}$ peak and by the low values of their production indexes (Figure 4). The wide range of $T_{M}$ values is caused by the presence of reworked organic matter.

Production indexes generally remain below 10 per cent. The occasional exceptions could be caused by minute accumulation, or by pollution by shipboard lubricants. For low carbon content, such values must be interpreted with care.

\section{Sites 370 and $\mathbf{4 1 6}$}

These sites are characterized by a predominance of terrigenous sediments (Site 416 Report, this volume). I have supplemented samples from the poorly cored upper section of Hole 416A with samples from Hole 370, drilled during Leg 41 , only $2 \mathrm{~km}$ east of Site 416 .

\section{Vertical Distribution}

I have recognized seven groups (Figure 6) according to the criteria described above (see Vertical Distribution, Site 415).

Group 1, from 1616 to 1420 meters, includes the Tithonian, Berriasian and part of the Valanginian. It corresponds to lithologic Unit VII and is characterized by a low organic-carbon content and a low petroleum potential (respectively, $<0.3 \%$ and $<0.2 \mathrm{~kg} \mathrm{HC} /$ metric ton). The hydrogen index is also low, approximately 50 $\mathrm{mg} / \mathrm{g}$.

Group 2 corresponds to lithologic Unit VI, 1420 to 910 meters: upper Valanginian to lower Aptian. The

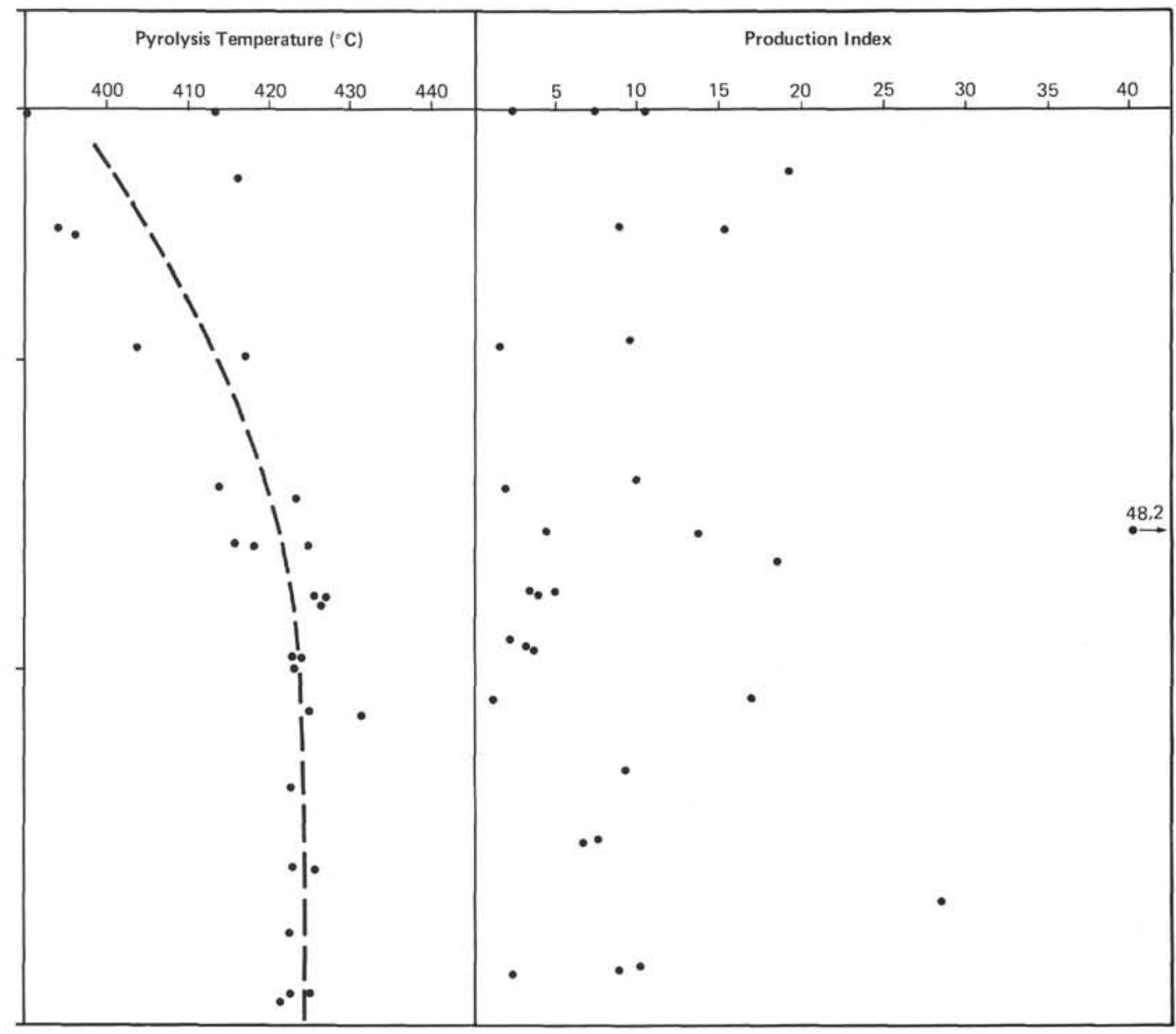

Figure 4. (Continued). 


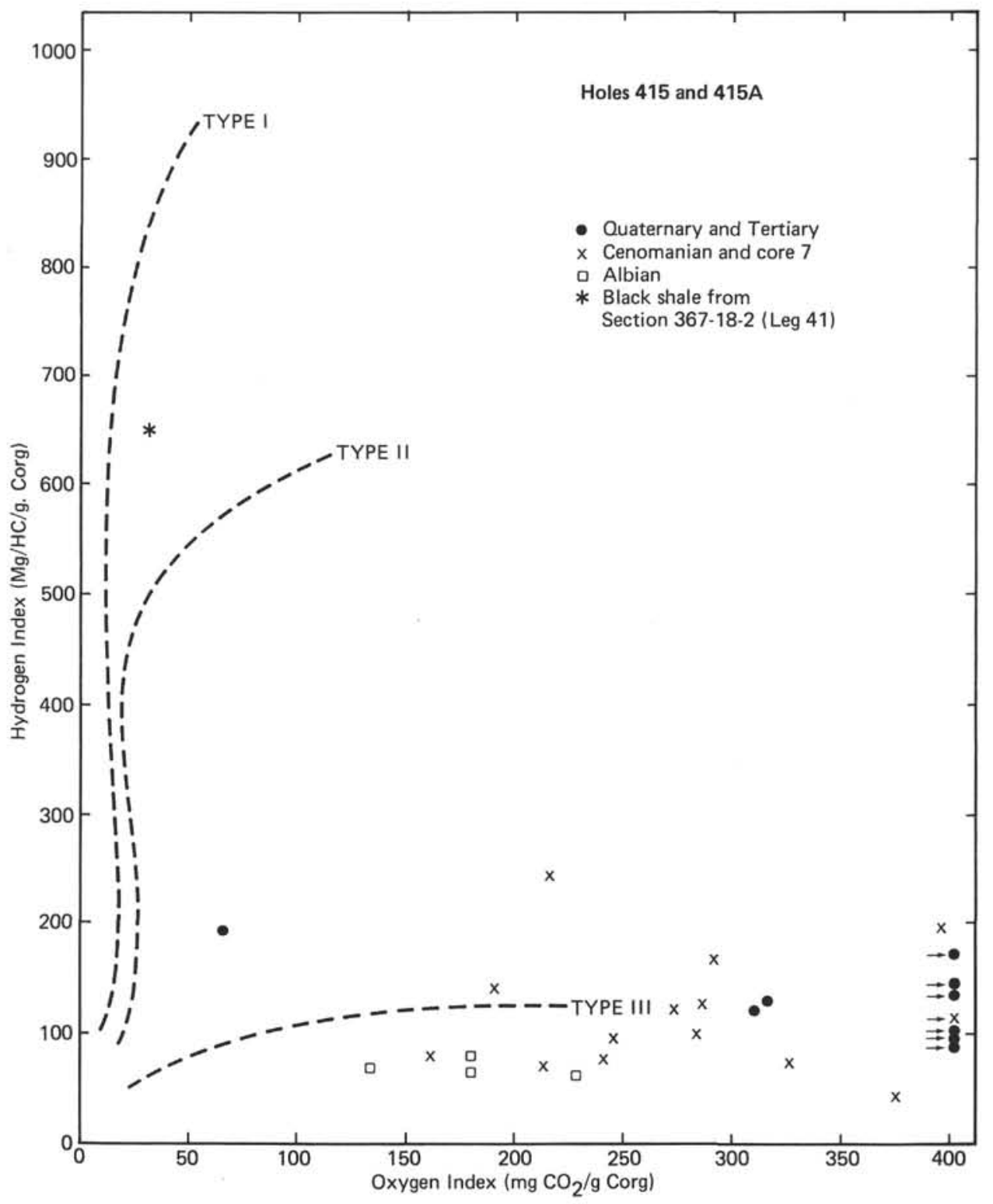

Figure 5. Hydrogen and oxygen indexes of samples from Site 415.

organic carbon contents are variable. The petroleum potential is between 0.2 and $1.0 \mathrm{~kg} \mathrm{HC} /$ metric ton and the hydrogen index values, between 50 and $150 \mathrm{mg} / \mathrm{g}$, are slightly higher than in group 1 .

Group 3 (910 to $830 \mathrm{~m}$ ) has an organic-carbon content between 1 and 2 per cent and a petroleum potential greater than $2 \mathrm{~kg} /$ metric ton. Hydrogen indexes are mainly between 150 and $300 \mathrm{mg} / \mathrm{g}$. Some samples in group 2 (1250 to $1200 \mathrm{~m}$ ) have the same characteristics as those in group 3 .

Group 4 ( 830 to $750 \mathrm{~m}$ ) corresponds principally to the Albian to Cenomanian. It contains less than 0.5 per cent organic carbon and has a petroleum potential between 0.2 and $1 \mathrm{~kg} /$ metric ton (Sample 416A-5, CC is an exception in this group). Hydrogen indexes are between 150 and $300 \mathrm{mg} / \mathrm{g}$.

Group $5(750$ to $620 \mathrm{~m})$, lower to middle Eocene, shows the same characteristics as group 2 .
Group 6 (620 to $500 \mathrm{~m})$ corresponds to the lower to middle Eocene, too. It is characterized by organiccarbon values greater than 1 per cent and petroleum potentials higher than $2 \mathrm{~kg} /$ metric ton. The hydrogen indexes are high, more than $300 \mathrm{mg} / \mathrm{g}$.

Group 7, from 500 meters to the top of the hole, includes the upper Oligocene through Pleistocene; it has variable organic-carbon contents $(0.1 \%$ to $1.1 \%)$ and petroleum potentials ( 0.1 to $2 \mathrm{~kg}$ /metric ton). Hydrogen indexes are usually between 3.5 and $4.5 \mathrm{mg} / \mathrm{g}$.

\section{Interpretation and Relationship with Sedimentologic and Paleontologic Characteristics}

As shown by Figures 6 and 7, hydrogen indexes are low in the majority of samples containing type III kerogen, which is probably continental in origin (Tissot et al., 1974). Middle-Eocene, Albian to Cenomanian, and Aptian samples have higher hydrogen indexes, indi- 
cating a mixing of both marine and continental organic matter. At Site 415, the low values of hydrogen indexes can be explained by the presence of reworked, altered organic matter, which could mask a weak contribution of marine organic matter. This assumption is supported by visual observation made during reflectance analysis (Boutefeu et al., this volume). Furthermore, analysis of samples from Sections 370-22-2 and 370-34-4 (Kendrick et al., 1978) shows results consistent with our analysis of samples belonging to the same group: 5 to 10 per cent reworked humic and inert organic matter (see also Deroo et al., this volume).

This abundance of terrestrial organic matter is confirmed by visual examination of samples (Boutefeu et al., this volume; Galimov et al., this volume); this is hardly surprising in view of the prevalence of turbidites in the section (Price, this volume).

The majority of samples in group 1 are brown mudstone, whereas in group 2 they are mainly graygreen or brownish-gray mudstone. In both cases the mudstone represents the " $D$ " and "E" intervals of the Bouma cycle (Site 416 Report, this volume). This difference in mudstone color may be related to difference in origin (Site 416 Report, this volume), which would explain the difference in the organic-carbon content.

Some fine-grained sandstones and siltstones are rich in macroscopic organic material (e.g., Samples 416A-16-2, $83-84 \mathrm{~cm} ; 22-4,3-5 \mathrm{~cm} ; 24-2,58-59 \mathrm{~cm} ; 24-2,64-65 \mathrm{~cm}$; and 26-1, 32-34 cm; Site 416 Report, this volume.) In these cases the samples with larger organic particles (from higher plants) have higher hydrogen indexes, which seems to indicate that the organic matter contained in fine clastic sediments is more altered than that in the coarse clastic sediments. Slight increases of the hydrogen indexes may be related to the more "proximal" character of certain turbidites, and therefore to a less-altered state of organic matter. This could also explain the high oxygen-index values of some samples. The oxygen indexes of samples with low carbon content, however, must be interpreted with caution. Turbidity currents are rapid phenomena and they cannot be the sole cause for the increase of hydrogen indexes.

The transition from group 5 to 6 approximately corresponds to a large change in the depositional environment and lithologic facies, which passes from hemipelagic mudstone and shale to turbidites. We have evidence that oceanic fertility was relatively high during that time (Site 416 Report, this volume). The high hydrogen-index values (between 330 and $530 \mathrm{mg} / \mathrm{g}$ ) of group 6 suggest a marine origin for organic matter, which might be related to increased plankton productivity as a consequence of this higher fertility.

The transition from group 6 to 7 corresponds approximately to a transition between more "proximal" and more "distal" turbidites consisting of diatom-rich nannofossil marl and chalk with sandstone and mudstone. The presence of diatoms and radiolarians suggests a relatively fertile overlying water mass (Site 416 Report, this volume). The low hydrogen indexes probably result from recycled and altered organic matter introduced by turbidity currents.

Groups 3 through 6 are also characterized by a positive correlation between organic-carbon and carbonate contents.

\section{Petroleum Potential and Maturation of Organic Matter}

Here again the majority of samples have more than the "minimum amount" of organic carbon $(0.4 \%$, Figure 6). Some samples from the Miocene and especially from the lower to middle Eocene and Aptian-Albian-Cenomanian sequences, contain more than the 1 per cent organic carbon which is often taken as a minimum value in order for a shale to be a potential source rock. Once again, however, the pyrolysis data are less favorable. Except for those from the middle Eocene and the Aptian-Cenomanian (groups 6 and 3), all samples yield less than $3 \mathrm{~kg}$ of oil per metric ton of rock and thus cannot qualify as potential petroleum source rocks.

The temperature of the $S_{2}$ peak is always lower than the $435^{\circ}$ to $440^{\circ} \mathrm{C}$ range (Figure 6) which is our definition of the beginning of the principal oil-formation zone. Some samples recovered from below 1400 meters, however, approach this value. Taken in conjunction with the increase of the production index, this suggests that the sediments below 1400 meters are near the very beginning of the mature zone. At Sites 416 and 370, however, the middle-Eocene and Aptian-Cenomanian potential source rock could not yet have produced hydrocarbons.

Assuming that the geothermal gradient is constant throughout the hole, and extrapolating the temperature recorded in the 400-meter logged section, we would expect a temperature of $50^{\circ} \mathrm{C}$ at total depth.

\section{CONCLUSIONS}

The Late Jurassic to Recent organic matter of the Moroccan Basin is principally of continental origin. This is in accord with the main type of sediment. Furthermore, the presence of recycled, altered and (or) oxygenated organic material diminishes the overall kerogen quality. This altered organic matter could be primary organic matter altered prior to and during deposition, and also reworked organic matter redeposited with turbidites, as suggested by visual analysis and slowpyrolysis analysis (Boutefeu et al., this volume). Redeposition would explain the low values of the hydrogen indexes and the poor petroleum potential.

\section{ACKNOWLEDGMENTS}

I am particularly indebted to Dr. B. Tissot (Institut Francais du Pérole) and Dr. G. E. Claypool (U.S. Geological Survey) for having kindly discussed and reviewed the manuscript.

\section{REFERENCES}

Barker, C., 1974. Pyrolysis techniques for source rock evaluation, Am. Assoc. Petrol. Geol. Bull., v. 58. 


\section{A. BOUTEFEU}

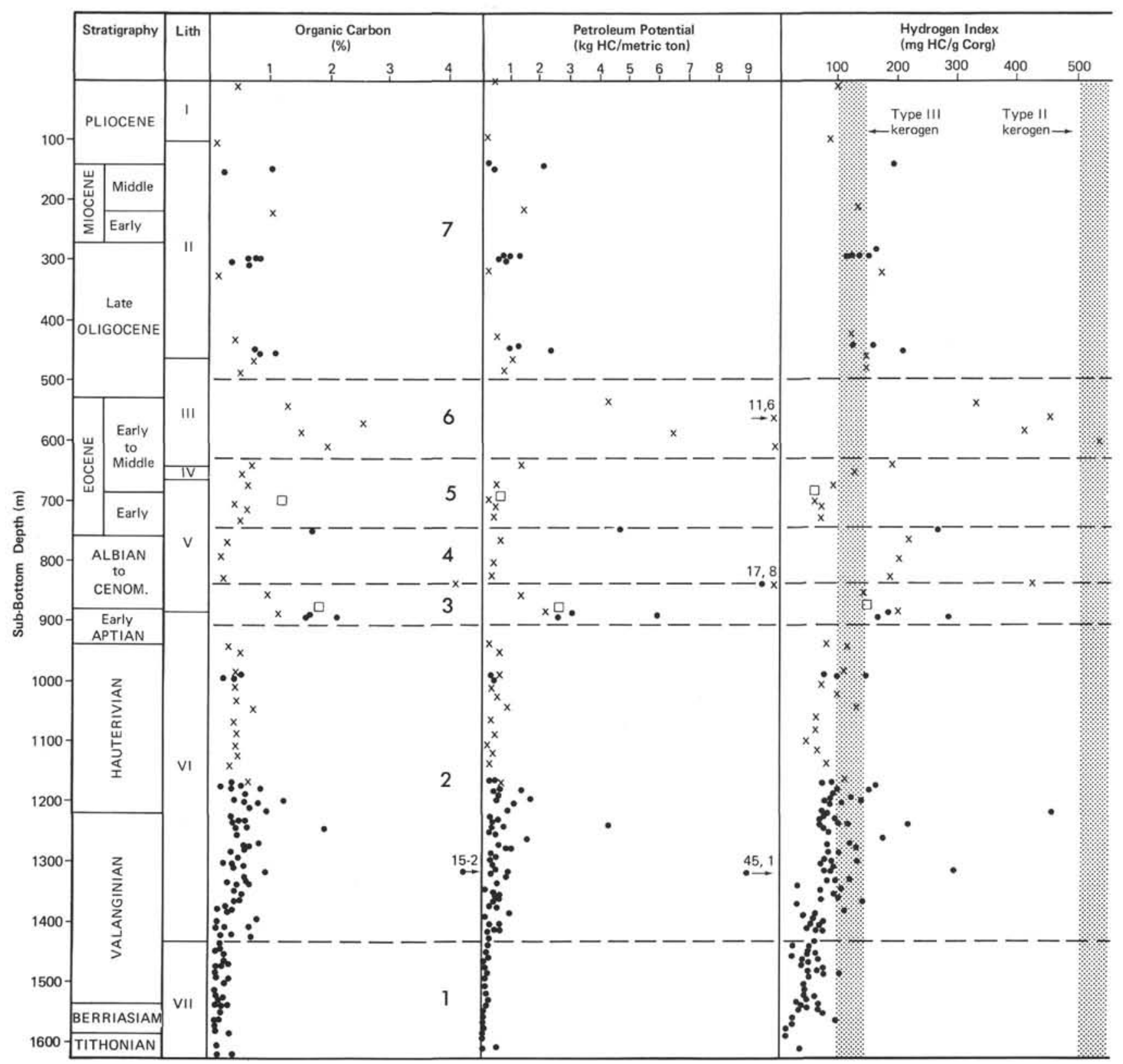

Figure 6. Vertical variations in organic-carbon content, petroleum potential, hydrogen index, pyrolysis temperature, and production index, Sites 370 and 416.

Claypool, G. E. and Reed, P. R., 1976. Thermal Analysis Technique for source rock evaluation: quantitative estimate of organic richness and effects of lithologic variation, $A m$. Assoc. Petrol. Geol. Bull., v. 60, no. 4, p. 608-612.

Espitalié, J., LaPorte, J. L., Madec, Marquis, F., Leplat, P., Paulet, J., and Boutefeu, A., 1977. Méthode rapide de caractérisation des roches mères, de leur potentiel pétrolier et de leur degré d'évolution, Rev. Inst. Franç. du pétrole, v. 32 , p. $23-42$.

Gallegos, E. J., 1975. Terpane-sterane release from kerogen by pyrolysis gas chromatography; mass spectometry, Anal. Chem., v. 47, p. 1524-1528.

Ishiwatari, R., Ishiwatari, M., Rohrback, B. G., and Kaplan, I. R., 1977. Thermal alteration experiments on organic matter from recent marine sediments in relation to petroleum genesis, Geochim. Cosmochim. Acta, v. 41, p. 815 828 .
Kendrick, J. W., Hood, A., and Castaño, J. R., 1978. Petroleum-generating potential of sediments from Leg 41, Deep Sea Drilling Project. In Lancelot, Y., Seibold, E., et al., Initial Reports of the Deep Sea Drilling Project, v. 41: Washington (U.S. Government Printing Office), p. 817-820.

Schmidt-Collerus, J. J. and Prien, C. H., 1974. Investigations of the hydrocarbon structure of kerogen from oil shale of the Green River Formation, Preprint of the Am. Chem. Soc. Div. of Fuel Chem., v. 19, p. 100-108.

Tissot, B., Durand, B., Espitalié, J., and Combaz, A., 1974. Influence of the nature and diagenesis of organic matter in the formation of petroleum, Am. Assoc. Petrol. Geol. Bull., v. 58, p. 499-506.

Yen, T. F., 1974. A new structural model of oil shale kerogen, Am. Chem. Soc. Div. Fuel Chem., v. 19, p. 109-114. (Preprint) 


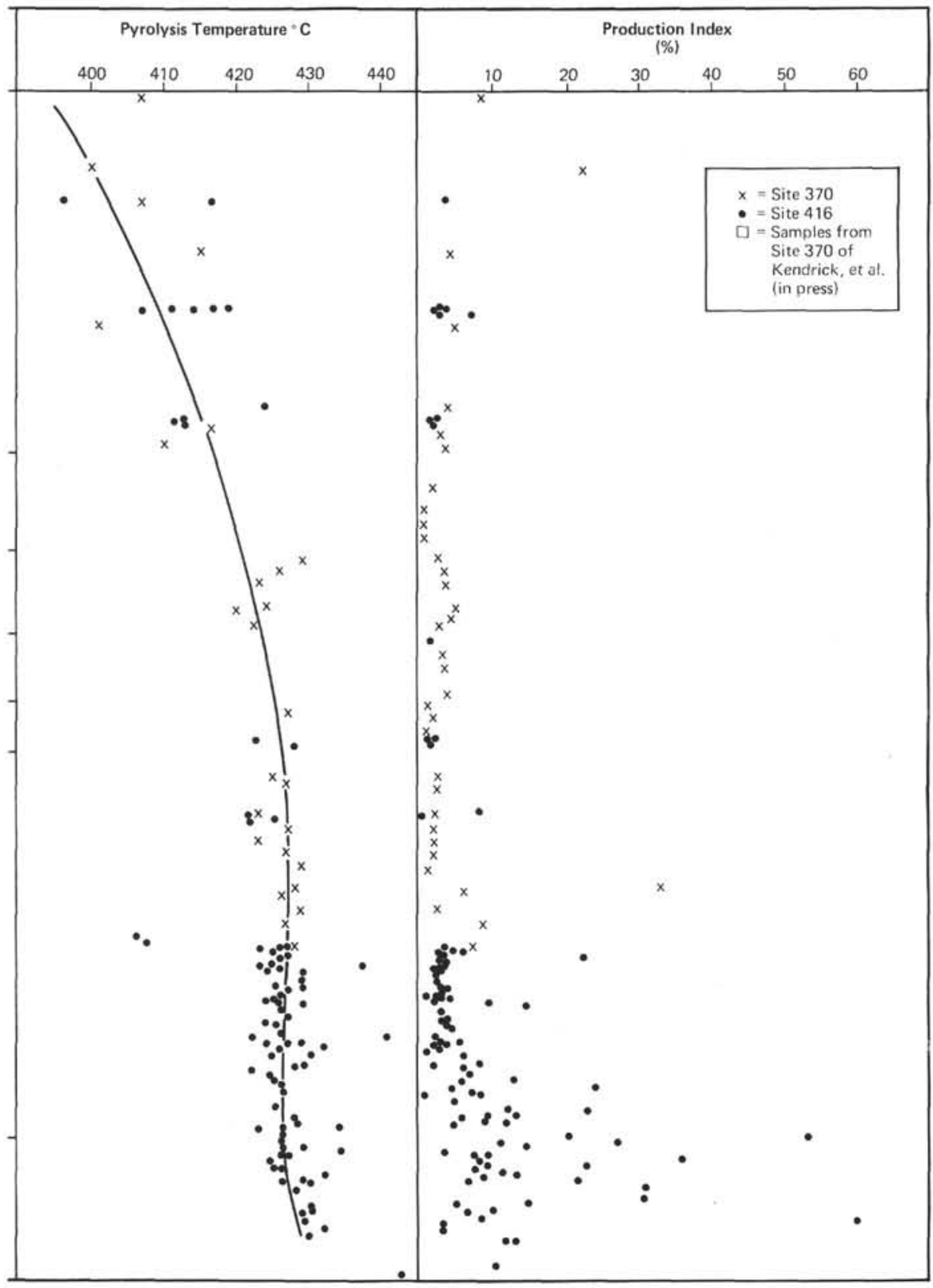

Figure 6. (Continued). 
A. BOUTEFEU

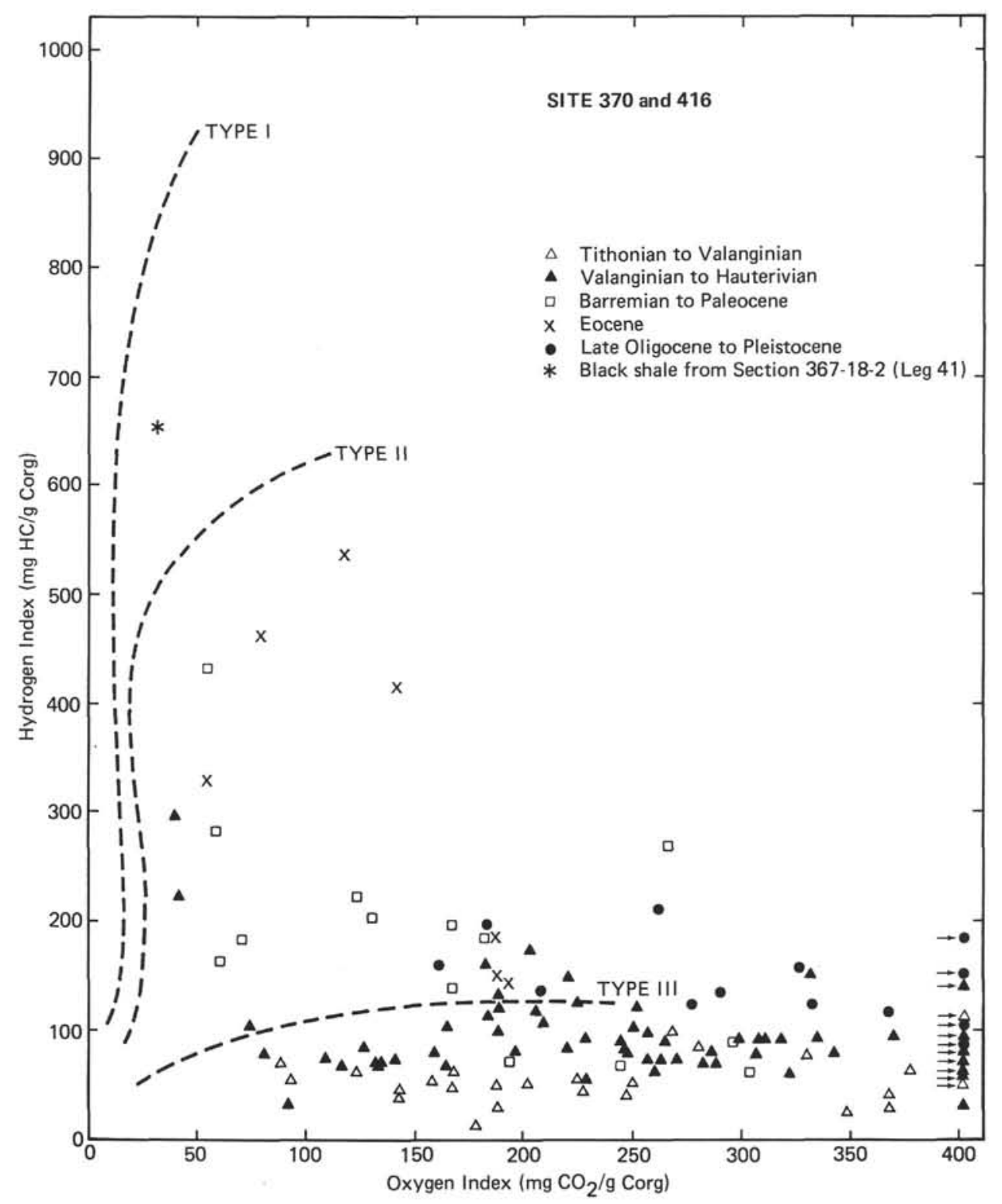

Figure 7. Hydrogen and oxygen indexes of samples from Sites 370 and 416. 